held jointly with the Atomic Energy Authority and the Central Electricity Generating Board. Patent examiners were again recruited with moderate success and the quality of recruits was higher than in previous years, but recruitment of patent oificers for the Ministry of Aviation was short of the Department's needs. Recruitment to the experimental officer class was generally satisfactory.

\section{Grants for Virus Study in Fiji}

The Fiji Islands are to be the setting for an investigation into common virus diseases. The investigation is to be financed jointly by the Wollcome Trust and by the Department of Technical Co-operation, with staff and services supplied by the University of Otago, New Zealand, and by the Fiji Government. In announcing the scheme on May 29, Prof. J. A. R. Miles (Otago), who will lead the investigation, pointed out that "the relative isolation of many of the populations of the islands in the Pacific makes them particularly suitable for the study of epidemics of common virus diseases. In large populations there are usually several viruses prevalent at any one time: quite often, in smaller and more remote communities, it is possible to study the effects of a single virus without interference by other agents. $\mathrm{Be}-$ cause of this and because of the evidence that virus infections are a very important health problem in the Fiji group of islands, the four bodies are co-operating to make a thorough study possible". With a grant from the Wellcome Trust a field laboratory is to be built and equipped (in association with the Colonial War Memorial Hospital in Suva) and a Land Rover is to be provided for field research. The Department of Technical Co-operation is to supply funds for the running of the laboratory and for the salaries of some of the staff. The Fiji Government will supply field staff and a laboratory worker, a site for the laboratory above the present hospital laboratories, services and transport. The Virus Laboratory of the Microbiology Department of the University of Otago is to act as base laboratory. It will direct the research, supply teams to work in Fiji during the long vacations and be responsible for the supply of trained staff and for organizing a training programme.

\section{The Ashmolean Museum, Oxford}

THe report of the Visitors of the Ashmolean Museum, Oxford, for 1963 states that certain galleries have been renamed to conform with recent changes in their contents (University of Oxford. Ashmolean Museum-Report of the Visitors, 1963. Supplement No. 8 to the University Gazette, March 1964. Pp. 85. Oxford: The University, 1964. 2s.). The Egyptian wall-paintings, of which the group of Akhenaten's children is the best known, have been cleaned and re-hung in the interior of the shrine from Tirhaka's Temple at Kawa. An Etruscan embossed bronze shield of the seventh century B.C., lent by Lord Howard de Walden, presented an unusual problem in restoration. With the help of the British Museum Laboratory, methods for the cleaning, preserving and remounting of this delicate object of almost paper-thinness have been worked out and are being applied effectively. The present congested conditions in the Coin Room affect adversely teaching and research, and alternative schemes for the extension of the premises exist. It is hoped that the University will develop one of these schemes in the near future.

\section{Archives and Manuscripts in Libraries}

A SECoND edition of Archives and Manuscripts in Libraries, by $\mathrm{P}$. Hepworth, first published in 1958, has been issued by the Library Association as Library Association Pamphlet No. 18 (Pp. $70+4$ plates. London: The Library Association, 1964. 12s. (members 9s.)). There are now four chapters dealing, respectively, with: definitions and history; archives and manuscripts in libraries; catalogues and guides to manuseripts in libraries (occupying rather more than half the pamphlet); and the archivist in the library. The bulk of the third chapter consists of lists of catalogues and guides arranged geographically, first under London, and then alphabetically under counties. These lists alone make the pamphlet a useful reference publication, and the remaining three chapters are provided with suggestions for further reading.

\section{The Alabama Academy of Science}

The Alabama Academy of Science was founded in 1924 and a Junior Academy was organized in 1933. A history: of the Academy, which has recently been published, gives a concise account of the activities of both bodies up to 1960 (Edited by Clyde H. Cantrell, Paul C. Bailey and S. B. Barker. Pp. $x+126$. Auburn, Alabama: Alabamar Academy of Science, 1963. 2 dollars). It includes their support of research, and the part they play in the organization of the Alabama State Science Talent Search, the Gorgas Scholarships, and Alabama Science Fairs. The Academy itself has relations with the Amcrican Association for the Advancement of Science, and the Junior Academy co-operates with the Science Clubs of America. This record of more than thirty years' effort indicates how valuable a part the scientific society can play in the world of to-day in securing public interest and understanding of science.

\section{New Compression and Transverse Testing Machine for Concrete}

RECENT years have witnessed considerable improvements in the manufacture of concrete products with commensurate increase in precision in their quality control. Collaterally, there has arisen a growing awareness, in both production and research laboratories engaged with concrete design and testing of the need for improvements in the machines normally used for testing in compression and for transverse testing. A newcomer in this range intended as an improved standard of testing is the Denison Model T.60CT compression testing machine, having a maximum capacity of 300 tons $x$ 0.5 ton; 120 tons $\times 0.2$ ton; 60 tons $\times 0.1$ ton, and the accuracy of load measurement to Grade $A$, B.S.S. 1610 : 1958. In this apparatus the load is measured by a strain gauge type load cell situated in a recess in the end of the setting screw of the straining unit. The latter is of rigid four-column construction, 24-in. column spacing, with cast steel base and cross-head. Standard platens are $12 \frac{1}{2}$-in ${ }^{2}$. hardened to 55 Rockwell ' $C$ ' Scale, and 'fiddles' are available for automatically centralizing 4 -in. and 6 -in. cubes on the platen. Adaptor plates are also supplied for testing building blocks up to $18 \times 9 \times 9$ in., with a maximum breaking load of 50 tons on this size. The attractively designed console unit has a potentiometric dial indicator 18 -in. diameter reading line, which responds to the electric signal from the load cell. A scale range selection system in the dial is electrically and mechanically interlinked, thus ensuring that correct figures are always seen in the dial windows. An integral part of the dial indicator is a Load Pacer adjustable from 4 to 70 per cent of full-scale deflexion per minute. Load is applied by an upstroking ram of 4-in. stroke built into the base of the straining unit and speed of loading is controlled by coarse and fine valves operating the variable displacement pump in the console. A 15-ton capacity compression and transverse unit, controlled from the same console as the 300 -ton unit, completes the system. It is claimed that with this apparatus ". . . the entire range of concrete cubes, eylinders aggregates, beams, kerbs flags, etc., can be tested to British Standard Specifications". The manufacturers of this testing machine are Samuel Denison and Son, Ltd., Leeds, from whom further details of the system can be obtained. 